\title{
Stent thrombosis caused by metal allergy complicated by protein $S$ deficiency and heparin-induced thrombocytopenia: a case report and review of the literature
}

\author{
Takao Konishi ${ }^{1,2^{*}}$, Tadashi Yamamoto ${ }^{1}$, Naohiro Funayama', Beni Yamaguchi', Seiichiro Sakurai , Hiroshi Nishihara ${ }^{2}$, \\ Koko Yamazaki', Yusuke Kashiwagi', Yasuki Sasa', Mitsuru Gima' ${ }^{1}$, Hideichi Tanaka', Daisuke Hotta ${ }^{1}$ and Kenjiro Kikuchi ${ }^{1}$
}

\begin{abstract}
A 43-year-old woman recipient of a bare metal coronary stent during an acute anterior myocardial infarction was repeatedly hospitalized with recurrent stent thrombosis (ST) over the following 3 years. Emergent coronary angiography showed a thrombus in the in-stent segment of the proximal left anterior descending artery. We repeatedly aspirated the thrombus, which immediately reformed multiple times. The discontinuation of heparin and administration of thrombolytics and argatroban, followed by repeated balloon dilatations, ended the formation of new thrombi. The patient was found to be allergic to nickel, protein $S$ deficient and carrier of heparin-induced thrombocytopenia antibody. We discuss this case in the context of a) literature pertaining to acute coronary syndromes in the young, and b) the detailed investigations needed to identify thrombotic risk factors. Steroids may be effective to prevent recurrent ST caused by stent allergy.
\end{abstract}

Keywords: Stent thrombosis, Metal allergy, Heparin-induced thrombosis, Protein S deficiency

\section{Background}

Stent thrombosis (ST) is a rare though critical complication of PCI, which may occur despite recent progress in antiplatelet therapy and procedural techniques. The incidence of ST ranges between 0.6 and $4.4 \%[1-5]$. However, the clinical consequences of ST include myocardial infarction in $70 \%$ to $80 \%$ or death in $30 \%$ of cases [6]. Therefore, ST remains an important clinical challenge in the modern era of stent deployment. There are many patient-related potential factors of ST such as smoking, diabetes mellitus, chronic kidney disease and premature discontinuation or cessation of dual antiplatelet therapy [7]. So far, however, no reports exist mentioning ST caused by metal allergy complicated by protein $\mathrm{S}$ deficiency and heparin-induced thrombocytopenia.

\footnotetext{
* Correspondence: takaokonishi0915@gmail.com
'Department of Cardiology, Hokkaido Cardiovascular Hospital, 1-30, West 13,

* Correspondence: takaokonishi0915@gmail.com
'Department of Cardiology, Hokkaido Cardiovascular Hospital, 1-30, West 13, South 27, Chuou-ku, Sapporo 064-8622, Japan

${ }^{2}$ Department of Translational Pathology, Hokkaido University School of 2Department of Translatio
Medicine, Sapporo, Japan
}

\section{Case presentation}

A 43-year-old woman was admitted to the coronary care unit, complaining of prolonged chest pain that developed while playing a mobile game at home. Acute coronary syndrome (ACS) was diagnosed from the electrocardiogram, which showed a 1-mm ST segment elevation in the precordial leads V1-V4 and reciprocal, 1-mm ST segment depression in leads I and $\mathrm{aVL}$, with abnormal Q waves in V1-V3. Her coronary risk factors were dyslipidaemia and current smoking. She had undergone a) implantation of a $4.0 \times 18.0 \mathrm{~mm}$ Driver $^{\mathrm{Tm}}$ (Medtronic, Inc., Minneapolis, $\mathrm{MN}$ ) bare metal stent in the proximal left anterior descending (pLAD) artery 3 years earlier for management of a first ACS with myocardial infarction, and b) percutaneous coronary intervention (PCI) and thrombus aspiration 12 months later for treatment of a 2nd ACS due to instent thrombosis. After having being treated with warfarin for 2 years to prevent ST, the international normalized ratio had fallen between 1.1 and 1.3 (below the optimal therapeutic range), because of anaemia due to abundant 
menstrual haemorrhages, and she was re-hospitalized for treatment of her 3rd ACS.

On physical examination, her pulse was $80 \mathrm{bpm}$, blood pressure $128 / 83 \mathrm{mmHg}$, and a 3rd heart sound was audible on auscultation. The laboratory tests revealed a $21.0 \times 10^{3} / \mu$ l white blood cell count with $96.5 \%$ neutrophils, a platelet count of $42.2 \times 10^{4} / \mu \mathrm{l}$, a $7.3 \mathrm{~g} / \mathrm{dl}$ haemoglobin concentration, 63.0 and $5.3 \mathrm{IU} / \mathrm{l}$, CK and CK-MB concentrations, respectively, negative H-FABP, and $0.8 \mu \mathrm{g} /$ $\mathrm{ml} \mathrm{d}$-dimer and $0.02 \mathrm{mg} / \mathrm{dl} \mathrm{C}$-reactive protein serum concentrations. She immediately received 5,000 units of unfractionated heparin in a single bolus, followed by another 5,000 units bolus in the catheterization laboratory, before undergoing emergent coronary angiography, which revealed the presence of stent thrombosis (ST) and TIMI 2 distal flow in the pLAD artery (Fig. 1). An intravascular ultrasound study showed an in-stent fibrous thrombus in the pLAD artery (Fig. 2). After each aspiration of the thrombus with a special catheter, a large, red thrombus reappeared, requiring 10 consecutive aspirations over $45 \mathrm{~min}$ (Fig. 3). Suspecting heparin-induced thrombocytopenia (HIT), we discontinued the administration of heparin and substituted argatroban. Balloon angioplasty was performed, without further recurrence of thrombus, and the patient, finally chest pain free, stabilized clinically and was discharged from the hospital on the 27th day on a regimen of dabigatran instead of warfarin.

During her hospitalization, the patient underwent investigations of the cause of ST, including a patch test, blood coagulation test and HIT antibody. The skin patch test showed a positive response to nickel, a metal included in the composition of the Driver stent. Protein C, antithrombin III, antinuclear antibody, anticardiolipin 2glycoprotein I complex antibody and lupus anticoagulant were within normal limits, though the concentration of protein S (PS) was $35 \%$ (normal $=60-150 \%$ ), total PS antigen was $56 \%$ (normal $=65-135 \%)$ and free PS antigen was $50 \%$ (normal $=60-150 \%$ ). PS deficiency is classified as type I (decreased concentration of total and free PS antigen), type II (decreased activity of activated protein C-cofactor and normal total and free PS antigen concentration), and type III (decreased concentration of free PS antigen only) [8]. This patient presented with type I PS deficiency. The HIT test showed a weakly positive reaction: $\operatorname{IgG} \cdot \operatorname{IgM} \cdot \operatorname{IgA} 1.3 \mathrm{U} / \mathrm{ml}$ (normal $\leq 1.0 \mathrm{U} /$ $\mathrm{ml})$. Intravascular ultrasound study during PCI showed no incomplete stent apposition or stent fracture. The patient had been compliant with antiplatelet therapy before her admission to the hospital, including aspirin $100 \mathrm{mg} / \mathrm{day}$ and clopidogrel $75 \mathrm{mg} /$ day, and was not using oral contraception.

The patient was discharged from the hospital on a regimen of dabigatran, $300 \mathrm{mg} /$ day, later replaced by rivaroxaban, $15 \mathrm{mg} /$ day, instead of warfarin. However, she suffered a 4th ST in the pLAD artery 4 months later and, despite the prescription of the anti-allergic agent, fexofenadine, $120 \mathrm{mg} /$ day, she experienced a 5th ST 1 month later. Prednisolone, gradually tapered from 25 to $5 \mathrm{mg} /$ day, was added and the patient remained free from ST over a $>18$-month follow-up. This clinical course suggested that her recurrent thrombotic events were caused mainly by a stent allergy, and that PS deficiency and HIT are associated with ST.

\section{Discussion}

The pathophysiology of ST includes lesion-, stent-, procedure-, and patient-related factors. Early ST are often associated with lesion-or procedural factors, such as insufficient expansion of the stent, edge dissection, compromised flow and location of the stent at a bifurcation [9]. On the other hand, late and very late ST are associated with a variety of causes, such as local hypersensitivity reaction, poor endothelialization, inflammation,
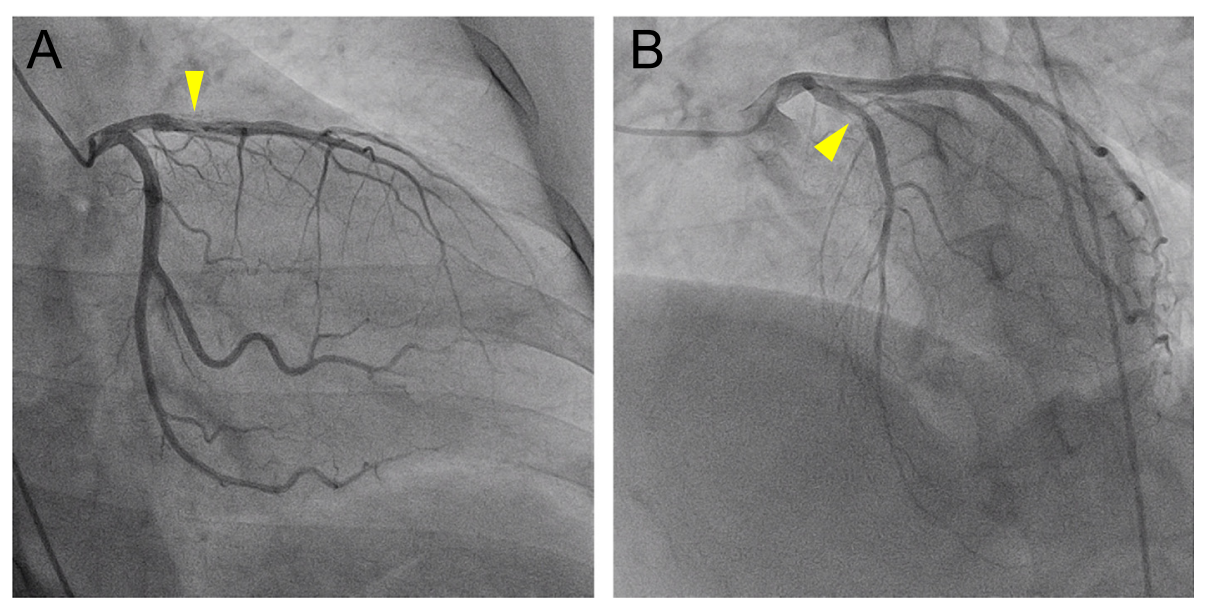

Fig. 1 Coronary angiography. a. Right anterior oblique and caudal view. b. Left anterior oblique and cranial view. A stent thrombosis is visible (arrowheads) in the in-stent segment of the proximal left anterior descending artery 


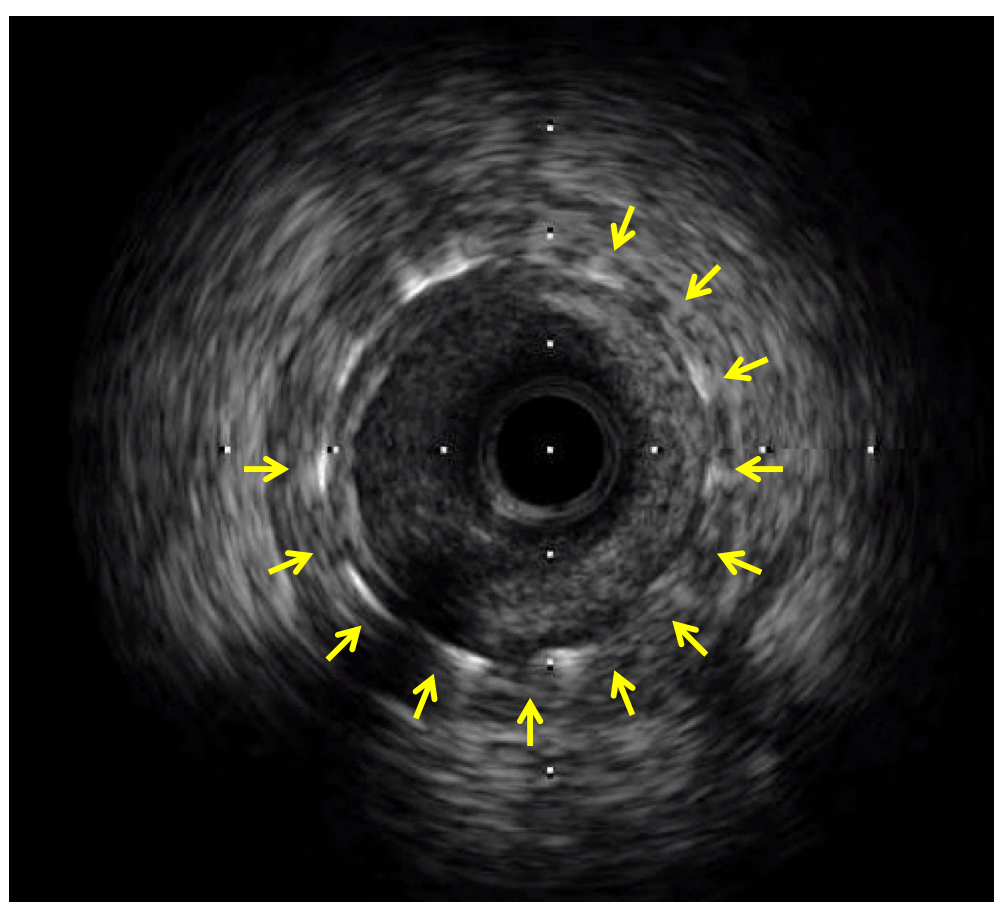

Fig. 2 Intravascular ultrasound. Fibrous thrombi are visible in the in-stent segment of the pLAD artery

delayed healing and neoatherosclerosis $[10,11]$. To the best of our knowledge, this is the first report of ST caused by metal allergy complicated by PS deficiency and HIT in a young woman.

\section{Stent allergy}

ST or in-stent restenosis (ISR) due to stent allergy have been reported [12-15]. Aliagaoglu et al. reported nickel allergies confirmed by patch tests in 7 of 31 patients (23\%) who developed ISR, while none of 30 patients free from ISR had an allergy to nickel $(\mathrm{p}<0.01)$ [12]. Koster et al. reported that 10 of 89 patients $(11 \%)$ who developed restenosis after PCI had positive reactions to nickel or molybdenum, which are standard components of metal stents [14]. Furthermore, the prevalence of nickel allergy in the general population is as high as $17 \%$ in women and $3 \%$ in men [16]. These observations suggest that stent allergy is an important risk factor of ST.

The mechanism of ST caused by metal allergy is a local endothelial inflammation and excessive immune

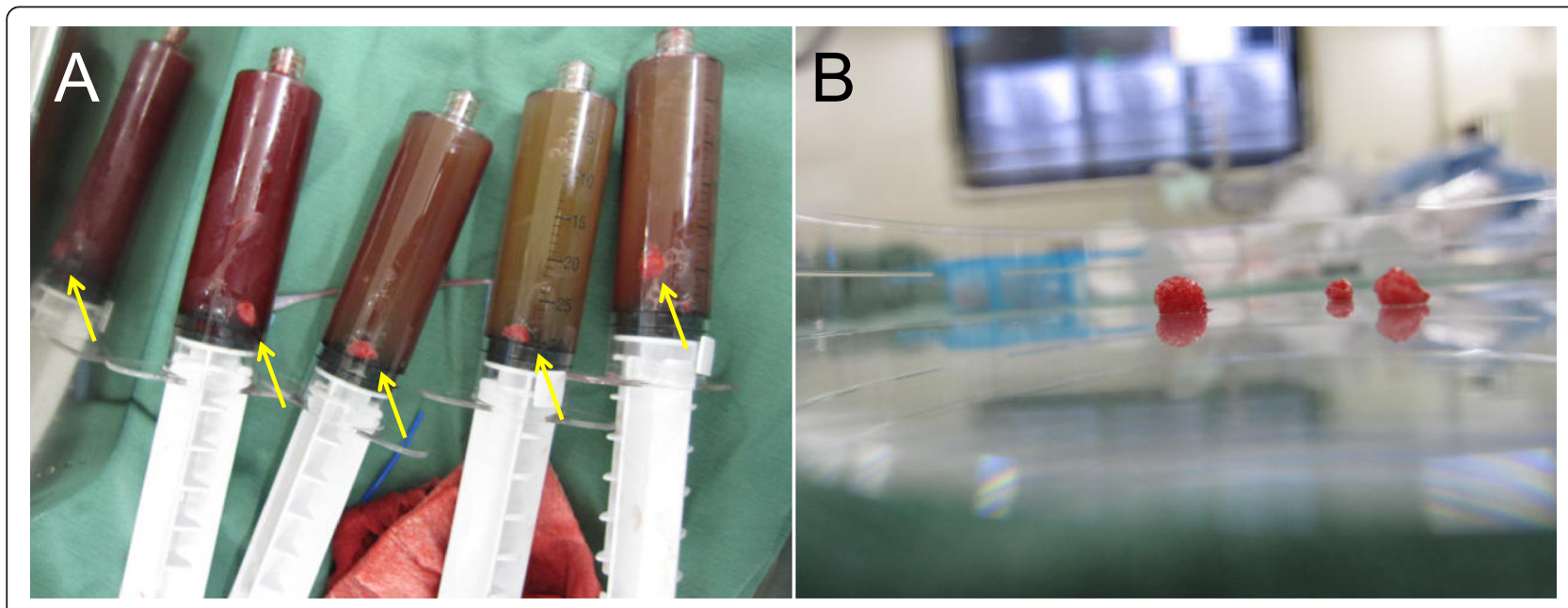

Fig. 3 Aspirated thrombi. a. Several large thrombi (arrow) were aspirated during PCl and preserved in physiologic saline inside the aspiration device. b. Extracted thrombi on a Petri dish 
response. After the implantation of a stent that contains nickel, the metal is steadily released into the systemic circulation, promoting the expression of intercellular adhesion molecule-1 on endothelial cells, which plays an important role in the recruitment of inflammatory cells from the bloodstream $[17,18]$. In addition, local exposure to a stent containing nickel causes a type IV hypersensitivity mediated by allergen-specific $\mathrm{T}$ lymphocytes, which can trigger excessive immunologic reactions $[19,20]$. Once nickel sensitization has occurred, it may persist for many years [21]. Since the bare metal stent implanted in this patient contained cobalt, nickel, chromium and molybdenum, a risk of ST was present since the stent implantation 3 years earlier. Therefore, patients who develop repetitive ST after implantation should undergo patch testing in search of metal allergy.

A significant increase in white blood cells, including eosinophils, does not occur systematically after implantation of coronary stents in metal allergic patients presenting with ISR [22]. Because of a paucity of Langerhans cells compared to the skin, the placement of stents in the coronary vessels triggers a weak immunological response [21]. Therefore, it is likely that, as illustrated in this case, an allergy to a metallic stent triggers an increase in eosinophil count consistent with a local instead of a systemic allergic reaction. In a post mortem study, eosinophilic infiltrations were observed at the site of the stent in patients with ST associated with stent allergies [23]. In our case, the histology showed eosinophilic infiltrates in part of the aspirated thrombus (Fig. 4), suggesting that a local stent allergic reaction was associated with ST.
Since inflammation is one of the main causes of ST or ISR $[24,25]$, the systemic administration of antiinflammatory or immunosuppressive therapy might be appropriate when a metal allergy is confirmed or strongly suspected. The implantation of a stent causes a prolonged recruitment of inflammatory cells [26]. In recent studies, the administration of oral steroids after PCI suppressed the vascular inflammation and lowered the rates of ST, ISR, or both [27-33]. For example, in the CEREA-DES trial, the adverse event-free survival of 125 recipients of bare metal stent alone was $75 \%$, versus $84 \%$ in 125 prednisone-treated patients, a significant difference [32]. Chronic inflammation and endothelial dysfunction induce neoatherosclerosis on the long term inside both bare metal stent and drug eluting stent (DES), and the disruption of neoatherosclerotic plaques plays an important role in the occurrence of late, and especially, very late ST [11, 34-36]. Considering that, in our patient, ST developed 5 times since the stent implantation, 3 years earlier, we hypothesize that a local inflammation caused by stent allergy promoted a persistent thrombogenic propensity and multiple thrombotic events during that period.

While warfarin or new oral antithrombotic agents must be administered in patients who develop ST after PCI [37-39], low-dose steroids in addition to dual antiplatelet therapy might prove effective, especially for patients who develop ST due to stent allergy, provided they do not suffer from diabetes or other contraindications to steroids. Unlike pharmacologic doses of glucocorticoids, which seem to increase the risk of adverse cardiovascular events [40], low doses of steroids might

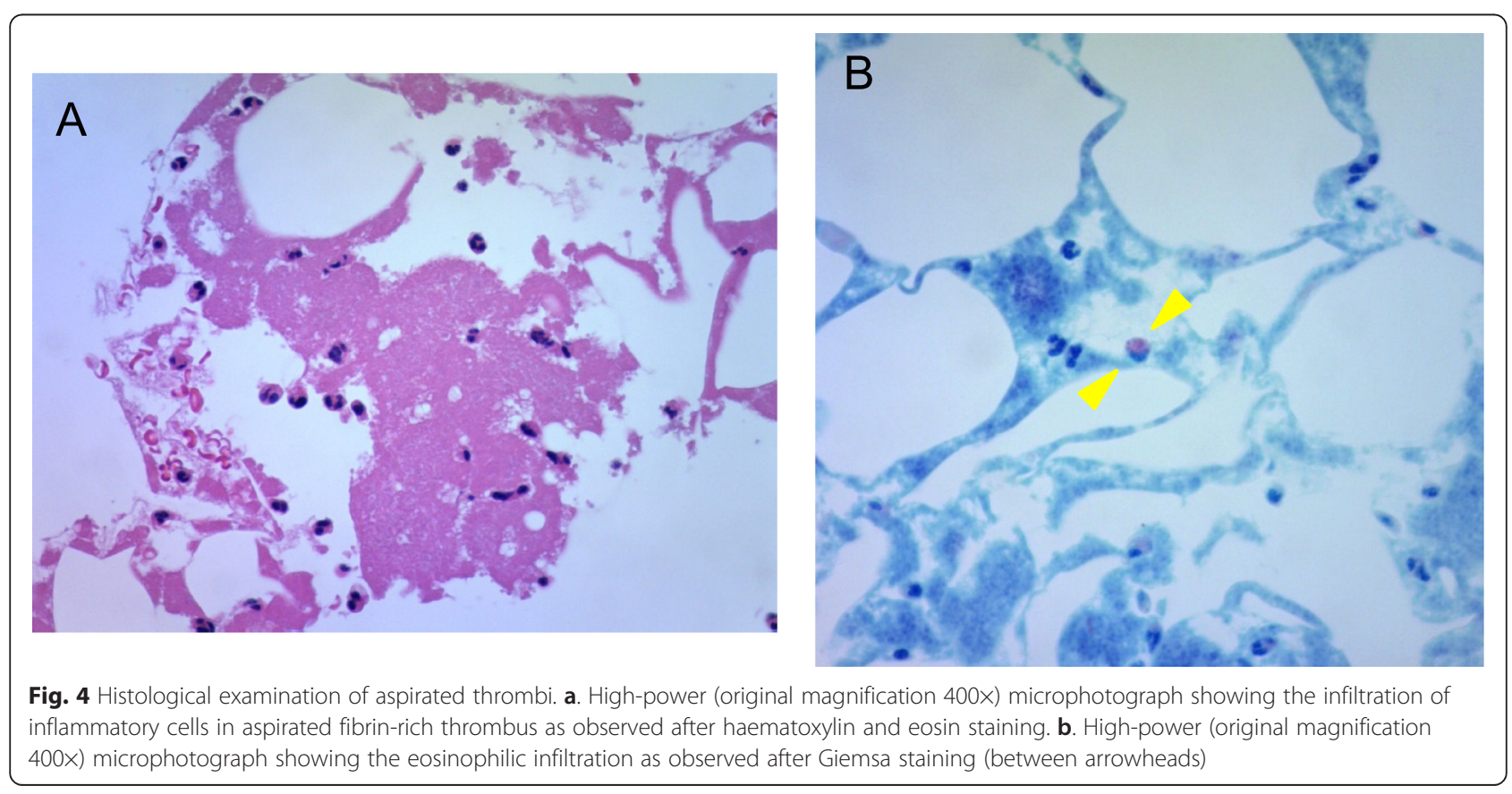


confer clinical benefits and lower the incidence of ST by their anti-inflammatory properties. The relative risk of adverse cardiovascular events in recipients of $\geq 7.5 \mathrm{mg}$ of prednisolone equivalent on the long term was 2.56 [40]. In contrast, in another study, oral prednisone lowered significantly the cumulative incidence of major adverse cardiovascular events, including ST [32]. The prednisone regimen consisted of $1 \mathrm{mg} / \mathrm{kg}$ for the first 15 days after stent implantation, $0.5 \mathrm{mg} / \mathrm{kg}$ from day 16 to day 30 , and $0.25 \mathrm{mg} / \mathrm{kg}$ from day 31 to day 40 . In this patient, an initial dose of $25 \mathrm{mg} /$ day of prednisolone was tapered by $5 \mathrm{mg}$ every month to a maintenance dose of $5 \mathrm{mg} /$ day. The dose of prednisolone remained unchanged and no further ST was observed.

Stent extraction followed by coronary artery bypass graft is an alternate means of management of ST due to stent allergy [41-43]. Likewise, recent studies have reported a low incidence of ST after implantation of bioresorbable vascular scaffolds, which may be particularly useful in patients presenting with stent allergy undergoing PCI $[44,45]$. After the elution of the anti-proliferative drug and the resorption of the scaffold, the risk of ST caused by metal allergy is markedly decreased. A direct comparison of anticoagulation versus resorbable stent versus steroid therapy would be of great interest to determine which is the most effective prevention of ST associated with stent allergy.

\section{Heparin-induced thrombocytopenia}

The incidence of heparin-induced thrombocytopenia (HIT) ranges between 0.3 and $5.0 \%$ of patients exposed to unfractionated heparin [46-48]. Women are more likely than men to develop HIT with an approximate relative risk of 1.5 to 2.0 [49, 50]. HIT is closely associated with thrombotic events, with a $20-40$ odds ratio for thrombosis, and a thrombotic risk ranging between 38 and $76 \%$ [50] and a $10.2 \%$ mortality rate [51]. Therefore, a prompt diagnosis of HIT is key when patients administered heparin present with thrombocytopenia or thrombosis.

While the platelet count in this patient was within normal limit, the relative change in platelets instead of the absolute platelet count must be ascertained [52, 53]. The evolution of our patient's platelet count is shown in Fig. 5. A " $4 \mathrm{~T}$ " scoring system, widely used for the clinical diagnosis of HIT, includes 1) the degree of Thrombocytopenia, 2) the Timing of the fall in platelet count after heparin exposure, 3) the presence of Thrombosis, and 4) the exclusion of oTher causes of thrombocytopenia [54]. Our patient's $4 \mathrm{~T}$ score was 5 out of 8 , consistent with an intermediate probability of HIT. The positive predictive value of an intermediate $4 \mathrm{~T}$ score in a population at relatively high risk of HIT is approximately $45 \%$ [55]. The HIT Expert Probability score, based on the opinions of 26 expert clinicians [56], is a new pre-test probability model, which, using a cut-off score of 5 , has been associated with a
$100 \%$ sensitivity, $60 \%$ specificity and $55 \%$ positive predictive value in the detection of HIT [56]. The likelihood of HIT in our patient seemed relatively high, as her calculated score was 9. Her clinical presentation was also consistent with a relationship between HIT and acute coronary thrombosis during PCI. The administration of argatroban after the discontinuation of heparin prevented the formation of new thrombi during PCI. Furthermore, the platelet count decreased consistently when she was hospitalized and was administered heparin during emergent PCI or follow-up coronary angiography (Fig. 5). However, because her baseline platelet count was high and the lowest counts remained within normal limits, the cause of transient fall in platelet count was not recognized and investigated until the third hospitalization for ACS.

In presence of circulating HIT antibodies from a recent heparin exposure, a rapid-onset type of HIT usually develops within minutes or hours after the beginning of heparin treatment. Once the antibodies are formed, they may persist for up to 100 days after the administration of heparin [57]. Since the last ACS occurred approximately 2 years earlier, this seemed to be an atypical case of rapid onset. However, the minuscule doses of heparin contained in the heparin-coated infusions or heparin flushes of intravenous iron preparation she had received nearly monthly for abundant menstrual bleeding (Fig. 5) might have unknowingly activated the HIT antibodies.

HIT antibodies may be activated more prominently by high than by low doses of intravenous heparin, although this has not been prospectively examined in a large study. In a study by Chong, the incidence of HIT ranged between 1 and $30 \%$ among patients who received high doses of intravenous heparin, in contrast with $<2 \%$ in patients who received low doses of subcutaneous heparin [58]. Our patient received a bolus of 10,000 IU of unfractionated heparin during the PCI for the 3rd ACS, compared with 1,500-6,000 IU during the previous coronary angiograms or PCI (Fig. 5). This different dose of heparin might explain why a ST occurred during that PCI, and did not occur during the previous angiograms or PCI.

Since they interact with neither platelet factor 4 (PF4) nor anti-PF4/heparin antibodies, the new oral antithrombotics may be a valuable therapeutic alternative for patients who present with a history of HIT [59-61]. In our patient, warfarin was replaced by dabigatran at the time of hospital discharge and, later, dabigatran was replaced by rivaroxaban to promote compliance with treatment.

\section{Protein S deficiency}

The estimated prevalence of PS deficiency in the general population is $1-2 \%$ [62-64]. PS is a plasma protein that serves as a cofactor for the anticoagulant effects of activated protein $\mathrm{C}$, which exists in 2 forms in plasma. Approximately $60 \%$ of PS is bound to the complement 


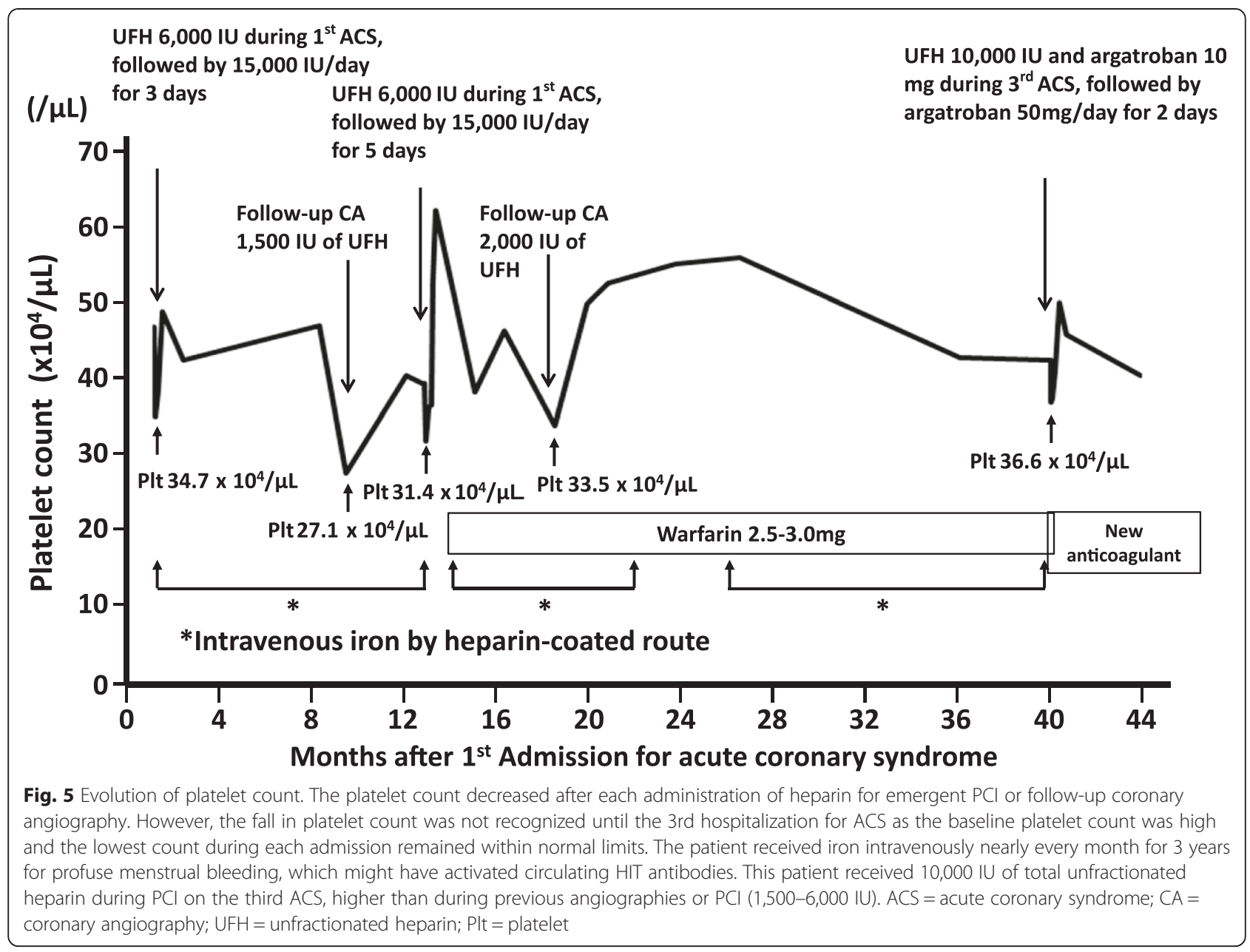

component $\mathrm{C} 4 \mathrm{~b}$ binding protein, and the remaining $40 \%$ is free [65]. PS C4b binding protein has a direct anticoagulant activity, although is less effective than free PS [66]. Recent studies have, in fact, found that free PS is a better indicator of thrombotic events than total PS $[67,68]$.

It is likely that, compared with other vitamin Kdependent proteins, the blood concentration of PS in this patient was relatively decreased. Although PS is a vitamin K-dependent coagulation factor, the antigen and activity of which are significantly reduced upon the initiation of warfarin therapy [69-71], its concentration is also decreased during long-term anticoagulation with warfarin [72-75]. Consequently, an accurate diagnosis of PS deficiency based on its blood concentrations may be challenging. We recommend comparing the relative changes in PS concentration with that of other vitamin K-dependent proteins, such as prothrombin, factors VII, IX and X. Table 1 lists the plasma factors that influenced this patient's thrombophilic tendency. It is noteworthy that all measurements of PS concentrations were decreased, whereas the activities of factor $\mathrm{X}$ and protein $\mathrm{C}$ both remained within normal limits.
PS deficiency is a risk factor for deep venous thrombosis and pulmonary thromboembolism, as well as arterial thrombosis, including myocardial infarction [64, 76-79] and, in some studies has been associated with a prominently increased risk of ST $[80,81]$. Since the PS activity of patients with a hereditary deficiency is 25 to $40 \%$ of that measured in normal individuals [8] while the PS concentration in patients treated with warfarin is decreased by approximately $50 \%$ [82], it is likely that, in this patient, PS had decreased enough to cause a thrombotic event. The hypercoagulable state due to the low PS concentration measured in this patient seems to have outweighed the

Table 1 Plasma factors influencing the thrombophilic propensity

\begin{tabular}{lcc}
\hline Test & Values (percent) & Normal range (percent) \\
\hline Total protein S antigen & 56 & $65-135$ \\
Free protein S antigen & 50 & $60-150$ \\
Protein S activity & 35 & $60-150$ \\
Protein C activity & 89 & $64-146$ \\
Anti-thrombin III activity & 95 & $80-130$ \\
Factor X & 81 & $70-130$
\end{tabular}


anticoagulant effect of warfarin. Thus, she might have developed a significant protein $\mathrm{S}$ deficiency and recurrent ST while receiving inadequate doses of warfarin. The discontinuation of warfarin and its replacement by a new antithrombotic agent gradually normalized the PS concentrations, from $64 \%$ at 1 month, to $78 \%$ at 4 months after her discharge from the hospital.

This patient suffered from an accelerated blood coagulation caused by a combination of a) persistent local inflammation due to stent allergy, b) HIT-associated hypercoagulability, and c) warfarin-induced protein S deficiency. The intra-procedural ST was probably caused mainly by HIT after the injection of heparin during PCI. Heparin was replaced by argatroban and warfarin by a new antithrombotic agent. However, ST recurred twice despite the administration of the new antithrombotic and anti-allergic pharmaceutical, though not after the initiation of steroid therapy, suggesting that 1) the thrombotic events were caused mainly by a stent allergy, and 2) PS deficiency and HIT were associated with ST.

\section{Conclusions and clinical implications}

While venous thrombosis and gangrene caused by HIT and PS deficiency have been reported [83, 84], this is the first case of ST associated with metal allergy in addition to HIT and PS deficiency. Our observations suggest that an allergy to the stent should be considered as a possible cause of recurrent ST after stent implantation in relatively young patients, who should undergo patch testing. In addition, a history of metal allergy should be meticulously explored before elective PCI. Besides antiplatelet therapy, steroids may effectively prevent ST caused by a metal allergy. Detailed examinations and the early identification of other aetiologies can prevent recurrent major thrombotic events. It is noteworthy that, once formed, circulating HIT antibodies may be activated by the regular use of heparin-coated vascular access, persist for years, and be the cause of life-threatening thrombotic events. When acute coronary thrombosis occurs during PCI, HIT should always be strongly considered, since the failure to promptly discontinue all heparin administration and initiate an alternate antithrombotic agent may the source of major morbidity and mortality.

\section{Consent}

Written informed consent was obtained from the patient for publication of this Case report and any accompanying images.

\section{Abbreviations}

ST: Stent thrombosis; PS: Protein S; HIT: Heparin-induced thrombocytopenia; ACS: Acute coronary syndrome; pLAD: Proximal left anterior descending; PCl: Percutaneous coronary intervention; ISR: In-stent restenosis; PF4: Platelet factor 4.

\section{Competing interests}

The authors declare that they have no competing interests.

\section{Authors' contributions}

HN gave support in diagnosing the pathological findings. The other authors were involved in the management of the patient. All authors contributed to the draft and revision of the manuscript and approved the final manuscript.

\section{Acknowledgments}

We thank Mr. Fujisawa, a medical engineer, for helpful cardiac images.

Received: 28 April 2015 Accepted: 25 May 2015

Published online: 23 July 2015

\section{References}

1. Jensen LO, Maeng M, Kaltoft A, Thayssen P, Hansen HH, Bottcher M, et al. Stent thrombosis, myocardial infarction, and death after drug-eluting and bare-metal stent coronary interventions. J Am Coll Cardiol. 2007;50:463-70.

2. de la Torre Hernandez JM, Alfonso F, Gimeno F, Diarte JA, Lopez-Palop R, Perez de Prado A, et al. Thrombosis of second-generation drug-eluting stents in real practice results from the multicenter Spanish registry ESTROFA-2 (Estudio Espanol Sobre Trombosis de Stents Farmacoactivos de Segunda Generacion-2). JACC Cardiovasc Interv. 2010;3:911-9.

3. Gomez-Lara J, Brugaletta S, Gomez-Hospital JA, Ferreiro JL, Roura G, Romaguera $\mathrm{R}$, et al. Everolimus-eluting stent versus bare metal stent in proximal left anterior descending ST-elevation myocardial infarction: insights from the EXAMINATION trial. Am Heart J. 2013;166:119-26.

4. Lee JM, Park KW, Han JK, Yang HM, Kang HJ, Koo BK, et al. Three-year patient-related and stent-related outcomes of second-generation everolimus-eluting xience $V$ stents versus zotarolimus-eluting resolute stents in real-world practice (from the multicenter prospective EXCELLENT and RESOLUTE-Korea registries). Am J Cardiol. 2014;114:1329-38.

5. Dangas GD, Caixeta A, Mehran R, Parise H, Lansky AJ, Cristea E, et al. Frequency and predictors of stent thrombosis after percutaneous coronary intervention in acute myocardial infarction. Circulation. 2011;123:1745-56.

6. Mauri L, Hsieh WH, Massaro JM, Ho KK, D'Agostino R, Cutlip DE. Stent thrombosis in randomized clinical trials of drug-eluting stents. N Engl J Med. 2007;356:1020-9.

7. Kirtane AJ, Stone GW. How to minimize stent thrombosis. Circulation. 2011;124:1283-7.

8. Boyer-Neumann C, Bertina RM, Tripodi A, D'Angelo A, Wolf M, Vigano D'Angelo S, et al. Comparison of functional assays for protein S: European collaborative study of patients with congenital and acquired deficiency. Thromb Haemost. 1993;70:946-50.

9. van Werkum JW, Heestermans AA, Zomer AC, Kelder JC, Suttorp MJ, Rensing BJ, et al. Predictors of coronary stent thrombosis: the Dutch stent thrombosis registry. J Am Coll Cardiol. 2009;53:1399-409.

10. Joner M, Finn AV, Farb A, Mont EK, Kolodgie FD, Ladich E, et al. Pathology of drug-eluting stents in humans: delayed healing and late thrombotic risk. J Am Coll Cardiol. 2006;48:193-202.

11. Nakazawa G, Otsuka F, Nakano M, Vorpahl M, Yazdani SK, Ladich E, et al. The pathology of neoatherosclerosis in human coronary implants bare-metal and drug-eluting stents. J Am Coll Cardiol. 2011;57:1314-22.

12. Aliagaoglu C, Turan H, Erden I, Albayrak H, Ozhan H, Basar C, et al. Relation of nickel allergy with in-stent restenosis in patients treated with cobalt chromium stents. Ann Dermatol. 2012;24:426-9.

13. lijima R, Ikari $Y$, Amiya E, Tanimoto S, Nakazawa G, Kyono H, et al. The impact of metallic allergy on stent implantation: metal allergy and recurrence of in-stent restenosis. Int J Cardiol. 2005;104:319-25.

14. Koster R, Vieluf D, Kiehn M, Sommerauer M, Kahler J, Baldus S, et al. Nickel and molybdenum contact allergies in patients with coronary in-stent restenosis. Lancet. 2000;356:1895-7.

15. Svedman C, Moller H, Gustavsson CG, Bruze M. Coronary restenosis and contact allergy to stent material. J Invasive Cardiol. 2010;22:528-35.

16. Thyssen JP, Menne T. Metal allergy - a review on exposures, penetration, genetics, prevalence, and clinical implications. Chem Res Toxicol. 2010;23:309-18

17. Wataha JC, O'Dell NL, Singh BB, Ghazi M, Whitford GM, Lockwood PE. Relating nickel-induced tissue inflammation to nickel release in vivo. J Biomed Mater Res. 2001;58:537-44. 
18. Messer RL, Wataha JC, Lewis JB, Lockwood PE, Caughman GB, Tseng WY. Effect of vascular stent alloys on expression of cellular adhesion molecules by endothelial cells. J Long Term Eff Med Implants. 2005;15:39-47.

19. Thomas P, Summer B, Sander CA, Przybilla B, Thomas M, Naumann T. Intolerance of osteosynthesis material: evidence of dichromate contact allergy with concomitant oligoclonal T-cell infiltrate and TH1-type cytokine expression in the peri-implantar tissue. Allergy. 2000;55:969-72.

20. Kornowski R, Hong MK, Tio FO, Bramwell O, Wu H, Leon MB. In-stent restenosis: contributions of inflammatory responses and arterial injury to neointimal hyperplasia. J Am Coll Cardiol. 1998;31:224-30.

21. Nguyen SH, Dang TP, MacPherson C, Maibach H, Maibach HI. Prevalence of patch test results from 1970 to 2002 in a multi-centre population in North America (NACDG). Contact Dermatitis. 2008;58:101-6.

22. Romero-Brufau S, Best PJ, Holmes Jr DR, Mathew V, Davis MD, Sandhu GS, et al. Outcomes after coronary stent implantation in patients with metal allergy. Circ Cardiovasc Interv. 2012;5:220-6.

23. Nebeker JR, Virmani R, Bennett CL, Hoffman JM, Samore MH, Alvarez J, et al. Hypersensitivity cases associated with drug-eluting coronary stents: a review of available cases from the Research on Adverse Drug Events and Reports (RADAR) project. J Am Coll Cardiol. 2006;47:175-81.

24. Farb A, Sangiorgi G, Carter AJ, Walley VM, Edwards WD, Schwartz RS, et al. Pathology of acute and chronic coronary stenting in humans. Circulation. 1999:99:44-52

25. Farb A, Weber DK, Kolodgie FD, Burke AP, Virmani R. Morphological predictors of restenosis after coronary stenting in humans. Circulation. 2002;105:2974-80

26. Rogers C, Welt FG, Karnovsky MJ, Edelman ER. Monocyte recruitment and neointimal hyperplasia in rabbits. Coupled inhibitory effects of heparin Arterioscler Thromb Vasc Biol. 1996;16:1312-8.

27. Ribichini F, Tomai F, De Luca G, Boccuzzi G, Presbitero P, Pesarini G, et al. Immunosuppressive therapy with oral prednisone to prevent restenosis after PCI. A multicenter randomized trial. Am J Med. 2011;124:434-43.

28. Rhen T, Cidlowski JA. Antiinflammatory action of glucocorticoids-new mechanisms for old drugs. N Engl J Med. 2005;353:1711-23.

29. Ferrero V, Ribichini F, Pesarini G, Brunelleschi S, Vassanelli C. Glucocorticoids in the prevention of restenosis after coronary angioplasty: therapeutic potential. Drugs. 2007;67:1243-55

30. Niccoli G, Montone RA, Ferrante G, Crea F. The evolving role of inflammatory biomarkers in risk assessment after stent implantation. J Am Coll Cardiol. 2010;56:1783-93.

31. Versaci F, Gaspardone A, Tomai F, Ribichini F, Russo P, Proietti I, et al Immunosuppressive therapy for the prevention of restenosis after coronary artery stent implantation (IMPRESS study). J Am Coll Cardiol. 2002;40:1935-42.

32. Ribichini F, Tomai F, Pesarini G, Zivelonghi C, Rognoni A, De Luca G, et al. Long-term clinical follow-up of the multicentre, randomized study to test immunosuppressive therapy with oral prednisone for the prevention of restenosis after percutaneous coronary interventions: Cortisone plus BMS or DES veRsus BMS alone to EliminAte Restenosis (CEREA-DES). Eur Heart J. 2013:34:1740-8.

33. Ribichini F, Joner M, Ferrero V, Finn AV, Crimins J, Nakazawa G, et al. Effects of oral prednisone after stenting in a rabbit model of established atherosclerosis. J Am Coll Cardiol. 2007;50:176-85.

34. Inoue K, Abe K, Ando K, Shirai S, Nishiyama K, Nakanishi M, et al. Pathological analyses of long-term intracoronary Palmaz-Schatz stenting; is its efficacy permanent? Cardiovasc Pathol. 2004;13:109-15.

35. Park SJ, Kang SJ, Virmani R, Nakano M, Ueda Y. In-stent neoatherosclerosis: a final common pathway of late stent failure. J Am Coll Cardiol. 2012;59:2051-7.

36. Yamaji K, Inoue K, Nakahashi T, Noguchi M, Domei T, Hyodo M, et al. Bare metal stent thrombosis and in-stent neoatherosclerosis. Circ Cardiovasc Interv. 2012:5:47-54

37. Lip GY, Huber K, Andreotti F, Arnesen H, Airaksinen KJ, Cuisset T, et al. Management of antithrombotic therapy in atrial fibrillation patients presenting with acute coronary syndrome and/or undergoing percutaneous coronary intervention/ stenting. Thromb Haemost. 2010;103:13-28.

38. Rubboli A, Saia F, Sciahbasi A, Bacchi-Reggiani ML, Steffanon L, Briguori C, et al. Outcome of patients on oral anticoagulation undergoing coronary artery stenting: data from discharge to 12 months in the Warfarin and Coronary Stenting (WAR-STENT) registry. J Invasive Cardiol. 2014;26:563-9.

39. Mega JL, Braunwald E, Murphy SA, Plotnikov AN, Burton P, Kiss RG, et al. Rivaroxaban in patients stabilized after a ST-segment elevation myocardial infarction: results from the ATLAS ACS-2-TIMI-51 trial (Anti-Xa Therapy to
Lower Cardiovascular Events in Addition to Standard Therapy in Subjects with Acute Coronary Syndrome-Thrombolysis in Myocardial Infarction-51). J Am Coll Cardiol. 2013;61:1853-9.

40. Wei L, MacDonald TM, Walker BR. Taking glucocorticoids by prescription is associated with subsequent cardiovascular disease. Ann Intern Med. 2004;141:764-70

41. Rabkin DG, Whitehead KJ, Michaels AD, Powell DL, Karwande SV. Unusual presentation of nickel allergy requiring explantation of an Amplatzer atrial septal occluder device. Clin Cardiol. 2009;32:E55-7.

42. Verma SK, Tobis JM. Explantation of patent foramen ovale closure devices: a multicenter survey. JACC Cardiovasc Interv. 2011;4:579-85.

43. Belohlavek J, Belohlavkova S, Hlubocky J, Mrazek V, Linhart A, Podzimek S. Severe allergic dermatitis after closure of foramen ovale with Amplatzer occluder. Ann Thorac Surg. 2013;96:e57-9.

44. Verheye S, Ormiston JA, Stewart J, Webster M, Sanidas E, Costa R, et al. A next-generation bioresorbable coronary scaffold system: from bench to first clinical evaluation: 6- and 12-month clinical and multimodality imaging results. JACC Cardiovasc Interv. 2014;7:89-99.

45. Onuma Y, Dudek D, Thuesen L, Webster M, Nieman K, Garcia-Garcia HM, et al. Five-year clinical and functional multislice computed tomography angiographic results after coronary implantation of the fully resorbable polymeric everolimus-eluting scaffold in patients with de novo coronary artery disease: the ABSORB cohort A trial. JACC Cardiovasc Interv. 2013;6:999-1009.

46. Kappers-Klunne MC, Boon DM, Hop WC, Michiels JJ, Stibbe J, van der Zwaan C, et al. Heparin-induced thrombocytopenia and thrombosis: a prospective analysis of the incidence in patients with heart and cerebrovascular diseases. Br J Haematol. 1997;96:442-6.

47. Chong BH, Chong JJ. Heparin-induced thrombocytopenia. Expert Rev Cardiovasc Ther. 2004:2:547-59.

48. Deitcher SR, Carman TL. Heparin-induced thrombocytopenia: natural history diagnosis, and management. Vasc Med. 2001;6:113-9.

49. Warkentin TE, Sheppard JA, Sigouin CS, Kohlmann T, Eichler P, Greinacher A Gender imbalance and risk factor interactions in heparin-induced thrombocytopenia. Blood. 2006;108:2937-41.

50. Battistelli S, Genovese A, Gori T. Heparin-induced thrombocytopenia in surgical patients. Am J Surg. 2010;199:43-51.

51. Warkentin TE, Kelton JG. A 14-year study of heparin-induced thrombocytopenia. Am J Med. 1996:101:502-7.

52. Hach-Wunderle V, Kainer K, Salzmann G, Muller-Berghaus G, Potzsch B. Heparin-related thrombosis despite normal platelet counts in vascular surgery. Am J Surg. 1997;173:117-9.

53. Klement D, Rammos S, v Kries R, Kirschke W, Kniemeyer HW, Greinacher A Heparin as a cause of thrombus progression. Heparin-associated thrombocytopenia is an important differential diagnosis in paediatric patients even with normal platelet counts. Eur J Pediatr. 1996;155:11-4

54. Warkentin TE. Heparin-induced thrombocytopenia: diagnosis and management. Circulation. 2004;110:e454-8.

55. Lillo-Le Louet A, Boutouyrie P, Alhenc-Gelas M, Le Beller C, Gautier I, Aiach $M$, et al. Diagnostic score for heparin-induced thrombocytopenia after cardiopulmonary bypass. J Thromb Haemost. 2004;2:1882-8.

56. Cuker A, Arepally G, Crowther MA, Rice L, Datko F, Hook K, et al. The HIT Expert Probability (HEP) score: a novel pre-test probability model for heparin-induced thrombocytopenia based on broad expert opinion. J Thromb Haemost. 2010;8:2642-50.

57. Warkentin TE, Kelton JG. Temporal aspects of heparin-induced thrombocytopenia. N Engl J Med. 2001;344:1286-92.

58. Chong BH. Heparin-induced thrombocytopenia. Aust N Z J Med. $1992 \cdot 22 \cdot 145-52$

59. Krauel K, Hackbarth C, Furll B, Greinacher A. Heparin-induced thrombocytopenia: in vitro studies on the interaction of dabigatran, rivaroxaban, and low-sulfated heparin, with platelet factor 4 and anti-PF4/ heparin antibodies. Blood. 2012;119:1248-55.

60. Linkins LA, Warkentin TE, Pai M, Shivakumar S, Manji RA, Wells PS, et al Design of the rivaroxaban for heparin-induced thrombocytopenia study. J Thromb Thrombolysis. 2014;38:485-92.

61. Walenga JM, Prechel M, Hoppensteadt D, Escalante V, Chaudhry T, Jeske WP, et al. Apixaban as an alternate oral anticoagulant for the management of patients with heparin-induced thrombocytopenia. Clin Appl Thromb Hemost. 2013;19:482-7.

62. Nomura T, Suehisa E, Kawasaki T, Okada A. Frequency of protein S deficiency in general Japanese population. Thromb Res. 2000;100:367-71. 
63. Miyata T, Kimura R, Kokubo Y, Sakata T. Genetic risk factors for deep vein thrombosis among Japanese: importance of protein S K196E mutation. Int J Hematol. 2006;83:217-23.

64. Lipe B, Ornstein DL. Deficiencies of natural anticoagulants, protein C, protein S, and antithrombin. Circulation. 2011;124:e365-8.

65. Dahlback B. The tale of protein $\mathrm{S}$ and $\mathrm{C} 4 \mathrm{~b}$-binding protein, a story of affection. Thromb Haemost. 2007;98:90-6.

66. Heeb MJ, Koenen RR, Fernandez JA, Hackeng TM. Direct anticoagulant activity of protein S-C4b binding protein complex in Heerlen heterozygotes and normals. J Thromb Haemost. 2004;2:1766-73.

67. Pintao MC, Ribeiro DD, Bezemer ID, Garcia AA, de Visser MC, Doggen CJ, et al. Protein $\mathrm{S}$ levels and the risk of venous thrombosis: results from the MEGA case-control study. Blood. 2013:122:3210-9.

68. ten Kate MK, van der Meer J. Protein S deficiency: a clinical perspective. Haemophilia. 2008;14:1222-8.

69. Binymin KA, Nasher M, Patel D. Warfarin-induced deep vein thrombosis. Int Med Case Rep J. 2014;7:123-5.

70. Esmon CT, Vigano-D'Angelo S, D'Angelo A, Comp PC. Anticoagulation proteins C and S. Adv Exp Med Biol. 1987;214:47-54.

71. Dahm M, Lotz J, Hafner G, Oelert H, Prellwitz W. Value of molecular markers for administration of anticoagulant therapy after heart valve replacement. Z Kardiol. 1998:87 Suppl 4:42-5.

72. D'Angelo A, Vigano-D'Angelo S, Esmon CT, Comp PC. Acquired deficiencies of protein S. Protein S activity during oral anticoagulation, in liver disease, and in disseminated intravascular coagulation. J Clin Invest. 1988;81:1445-54.

73. Takano K, lino K, Ibayashi S, Tagawa K, Sadoshima S, Fujishima M. Hypercoagulable state under low-intensity warfarin anticoagulation assessed with hemostatic markers in cardiac disorders. Am J Cardiol. 1994;74:935-9.

74. Martinez Del Pero M, Verma S, Espeso A, Griffiths M, Jani P. An unusual case of warfarin-induced pinna skin necrosis. J Laryngol Otol. 2009;123:685-8.

75. Takahashi H, Tatewaki W, Wada K, Shibata A. Plasma protein S in disseminated intravascular coagulation, liver disease, collagen disease, diabetes mellitus, and under oral anticoagulant therapy. Clin Chim Acta. 1989;182:195-208

76. Ogasawara N, Kijima Y, Ike S, Nakagawa Y, Takagi T, Hata T, et al. Hereditary protein $\mathrm{s}$ deficiency with a history of recurrent myocardial infarction. Circ $J$. 2003;67:166-8.

77. Manzar KJ, Padder FA, Conrad AR, Freeman I, Jonas EA. Acute myocardial infarction with normal coronary artery: a case report and review of literature. Am J Med Sci. 1997;314:342-5.

78. Green D, Otoya J, Oriba H, Rovner R. Protein S deficiency in middle-aged women with stroke. Neurology. 1992;42:1029-33.

79. Sultan A, Malik $H$. Recurrent cerebral infarctions in a young patient: combined protein C and S deficiencies. J Coll Physicians Surg Pak. 2013;23:813-4

80. Goel PK, Batra A. Protein C and/or protein S deficiency and occurrence of stent thrombosis: a hitherto unrecognized association. J Interv Cardiol. 2010:23:560-4.

81. Acar G, Dogan A, Altinbas A, Turker Y. Recurrent acute stent thrombosis associated with protein $C$ and $S$ deficiencies. Int J Cardiovasc Imaging. 2006;22:333-7.

82. Fair DS, Revak DJ. Quantitation of human protein $S$ in the plasma of normal and warfarin-treated individuals by radioimmunoassay. Thromb Res. 1984;36:527-35.

83. Warkentin TE. An overview of the heparin-induced thrombocytopenia syndrome. Semin Thromb Hemost. 2004;30:273-83

84. Warkentin TE. Heparin-induced thrombocytopenia: IgG-mediated platelet activation, platelet microparticle generation, and altered procoagulant/ anticoagulant balance in the pathogenesis of thrombosis and venous limb gangrene complicating heparin-induced thrombocytopenia. Transfus Med Rev. 1996:10:249-58.

\section{Submit your next manuscript to BioMed Central and take full advantage of:}

- Convenient online submission

- Thorough peer review

- No space constraints or color figure charges

- Immediate publication on acceptance

- Inclusion in PubMed, CAS, Scopus and Google Scholar

- Research which is freely available for redistribution 